\title{
Cultural Layer in the Stone Age Sites of Northeastern Siberia
}

\author{
V. V.Pitulko
}

For citation: Pitulko V.V. Cultural Layer in the Stone Age Sites of Northeastern Siberia. Vestnik of Saint Petersburg University. History, 2021, vol. 66, issue 3, pp. 867-889.

https://doi.org/10.21638/11701/spbu02.2021.311

The phenomenon of the cultural layer is a fundamental concept of archaeology and the main object of study in the practice of field research. Despite this, its definition, surprisingly, still remains undeveloped. The widely known classical definition leaves many important questions unanswered. Thus, what about the horizon, formed in the past by redeposition of material, especially if this is not obvious? Can the bone-bearing horizon (for example, bone deposit of the mammoth "graveyard") definitely human-created but lacking (completely or almost completely) of formal artifacts be regarded as a cultural layer? What about areas of primary archaeological contexts, the elements of which retain their original structure and interconnection, but have lost their original spatial position along with the block of matrix sediments? In similar cases, except for burial structures, the concept of culture-bearing deposits, representing a specific geological formation, will be much more universal. Then culture-bearing deposits are deposits locally enriched with traces of past human activities (artifacts, technological waste, biological remains, structures, i.e., cultural remains sensu lato) as a result of the transfer and accumulation of matter in the process of lithogenesis. It should be emphasized that up to $65 \%$ of the territory of Russia is the permafrost area, while that of the former permafrost zone was significantly larger and included currently unfrozen areas. The culture-bearing deposits of the Stone Age sites of the Late Pleistocene age represented in these regions undoubtedly experienced the impact of cryogenic processes. The study of the Stone Age sites in Eastern Siberia provides the richest opportunities and material for the development of this issue.

Keywords: culture-bearing deposits, Stone Age, Upper Palaeolithic, Arctic, permafrost, site formation process, deposition.

Vladimir V.Pitulko - PhD (History), Senior Research Fellow, Institute of the History of Material Culture, Russian Academy of Sciences, 18, Dvortsovaya nab., St. Petersburg, 191186, Russian Federation; pitulko.vladimir@gmail.com

Владимир Викторович Питулько - канд. ист. наук, ст. науч. сотр., Институт истории материальной культуры Российской Академии наук, Российская Федерация, 191186, Санкт-Петербург, Дворцовая наб., 18; pitulko.vladimir@gmail.com

This work is based on the field investigations of the Stone Age sites in northeastern Siberia carried out by the author as a result of his own research conducted in the region for the past thirty years. I would like to take this opportunity to express my deep gratitude to all participants of this hard work. I would also like to thank Svetlana Svyatko for participating in the translation of the article. The author would like to acknowledge the Russian Science Foundation (project no. 16-18-10265P RNF and 21-18-00457 RNF) for the support of the new cycle of research into the ancient past of the Russian Eastern Siberian Arctic.

Данное исследование основано на опыте полевого изучения памятников каменного века на северо-востоке Сибири, полученном автором в результате собственных исследований, проводимых в этом регионе на протяжении последних тридцати лет. Пользуясь случаем, хочу выразить огромную благодарность всем участникам этой нелегкой работы. Автор благодарит Светлану Святко за участие в подготовке перевода текста статьи. Выражаю признательность Российскому научному фонду (проекты № 16-18-10265П РНФ и 21-18-00457 РНФ) за поддержку нового цикла исследований древнего прошлого российской Восточной Сибирской Арктики.

(C) St. Petersburg State University, 2021 


\section{Культурный слой памятников каменного века Северо-Восточной Сибири}

\section{В. В. Питулько}

Для цитирования: Pitulko V. V. Cultural Layer in the Stone Age Sites of Northeastern Siberia // Вестник Санкт-Петербургского университета. История. 2021. Т.66. Вып. 3. С.867-889. https://doi.org/10.21638/11701/spbu02.2021.311

Феномен культурного слоя представляет собой фундаментальное понятие археологической науки и основной объект изучения в практике полевых исследований. Несмотря на это, его определение удивительным образом до сих пор остается неразработанным. Широко известное классическое определение культурного слоя оставляет без ответа многие важные вопросы. Как, например, быть с горизонтом, сформировавшимся в отдаленном прошлом в результате переотложения материала, в особенности, если данный факт неочевиден? Является или не является культурным слоем костеносный горизонт (например, отложения так называемых «кладбищ» мамонтов), определенно рукотворный, но лишенный (полностью или почти полностью) формальных артефактов? Как быть с участками первичных археологических контекстов, элементы которых сохраняют изначальную структуру и взаимосвязь, но утратили свое оригинальное пространственное положение вместе с блоком вмещающих отложений? В перечисленных и иных случаях, за исключением погребальных комплексов и сооружений, гораздо более универсальным будет понятие культуросодержащих отложений, представляющих собой специфическое геологическое образование. Специфика таких образований определяется фактом присутствия в них, в той или иной форме, следов человеческой деятельности. Таким образом, культуросодержащие отложения - это отложения, локально обогащенные следами прошлой человеческой деятельности (артефактами, технологическими отходами, биологическими остатками, структурами, т.е. культурными остатками sensu lato) в результате переноса и накопления вещества в процессе литогенеза. Следует подчеркнуть, что значительная часть территории России является областью распространения многолетнемерзлых пород (до 65 \%), а площадь былой криолитозоны была существенно большей и включала, в частности, и районы, в настоящий момент лежащие вне ее пределов. Культуросодержащие отложения памятников каменного века позднего плейстоцена, представленные в этих районах, несомненно, испытали воздействие криогенных процессов. Изучение памятников каменного века Восточной Сибири дает богатейшие возможности и материал для разработки данного вопроса.

Ключевые слова: культуросодержащие отложения, каменный век, верхний палеолит, Арктика, многолетняя мерзлота, формирование отложений археологических памятников, депозиционные процессы.

In order to ask a question, you must already know most of the answer.

Robert Sheckley

\section{Introduction}

Despite the undying interest of the community in problems associated with the phenomenon of cultural layer, which is undoubtedly a fundamental concept of archaeology and the main object of study in the practice of field research, surprisingly, its definition still remains undeveloped. Most often it is given in the classical formulation by 
A. V.Artsikhovsky and D. A. Avdusin, which interprets the cultural layer as "a historical system of layers formed as a result of human activity. The thickness of the cultural layer depends on many reasons and differs in various settlements, ranging from a few centimetres to 30-35 m. In the centre of Moscow, the thickness of the cultural layer reaches $8 \mathrm{~m}$ or more..." 1 . It is in this way that this formulation is presented, in particular, in many modern textbooks ${ }^{2}$. At the same time, we can note that the term "layer" itself, according to G. I. Medvedev" ${ }^{3}$, has no clear definition and retains a certain freedom in use. However, the presence of significant uncertainties is characteristic of the interpretation of other basic concepts of archaeology $y^{4}$, for example, "site" or "archaeological complex", which apparently indicates that the discipline is still undergoing the process of formation.

Conceptually, the cited definition of a "cultural layer" is correct (although the term "layer" itself is understood at an intuitive level), but it is only applicable to few isolated cases, i.e., where anthropogenic and/or technogenic deposits and formations are present in volumes locally comparable to those resulting from geological processes. These are relatively rare objects represented by massive deposits of proto-urban settlements and towns, including those still existing today and even not particularly ancient ${ }^{5}$, or physical traces of such objects transformed over time into landscape forms - tell/tel/tall/hüyük/tepe widely known in the semi-arid and arid zones of the northern hemisphere ${ }^{6}$.

Hence, it is obvious that in some cases the archeologisation of material evidence of the past human activity is incomplete as it finally terminates at the moment when the process of adding of new evidence of one or another kind to the accommodating sediments, associated with burying of the horizon with the findings by sediments free from them, ends. This is important as it indicates that, for example, the urban "cultural layer" of long-existing historical city will be accumulating until the city ceases to exist for one or

${ }^{1}$ Artsikhovskii A. V. Osnovy arkheologii. Moscow, 1955. P.4; Avdusin D. A. Polevaia arkheologiia v SSSR. Moscow, 1980; P.25-31; Aleksandrovskii A.L., Boitsov I.A., Krenke N.A. Pochvy i kul'turnyi sloi Moskvy: stroenie, istoriia razvitiia, geografiia // Izvestiia Rossiiskoi Akademii Nauk. Seriia Geographicheskaia. 1997. No. 4. P. 82-95.

2 See, for example: Martynov A. I. Archaeologiia. Moscow, 2005; Polyakov G. P., Shinakov E. A. Osnovy arkheologii. Bryansk, 2004; Yanin V.L. Archaeologiia. Moscow, 2006.

${ }^{3}$ Medvedev G. I. Fenomen geoarkheologicheskoi mnogosloinosti Baikal'skoi Sibiri // 100 let Baikal'skoi nauchnoi arkheologii: materialy Vserossiiskoi nauchoi konferentsii, posviashchennoi 100-letiiu so dnia otkrytiia. Irkutsk, 2012. P.5-9.

${ }^{4}$ Klejn L.S.: 1) Arkheologicheskie istochniki. Leningrad, 1978; 2) Istoriia arkheologicheskoi mysli. Vol.1. St. Petersburg, 2011. P.365-387; Dobrovolskaia M. V., Mazhaiskii A. Y. Archaeologiia. Moscow, 2012. P. 6-8.

${ }_{5}$ Aleksandrovskii A.L., Boitsov I.A., Krenke N.A. Pochvy i kul'turnyi sloi Moskvy. P.82-95; Dolgikh A. V., Aleksandrovskii A. L. Soils and cultural layers in Velikii Novgorod // Eurasian Soil Science. 2010. No. 43. P. 477-487; Howard J. F., Ryzewski K., Dubay B. R. et al. Artifact preservation and post-depositional site-formation processes in an urban setting: A geoarchaeological study of a $19^{\text {th }}$ century neighborhood in Detroit, Michigan, USA // Journal of Archaeological Science. 2015. Vol.53. P. 178-189; Mier M. F., Fernández J. F., González P. A. et al. The investigation of currently inhabited villages of medieval origin: Agrarian archaeology in Asturias (Spain) // Quaternary International. 2014. Vol.346. P. 41-55.

${ }^{6}$ See, for example: Avdusin D. A. Polevaia arkheologiia v SSSR. P. 69-71, 90-95; Drevnie tsivilizatsii / ed. by G. M. Bongard-Levin. Moscow, 1989. P.37-164; Yanin V.L. Archaeology. P. 8-27; Maghsoudi M., Simpson I. A., Kourampas N. et al. Archaeological sediments from settlement mounds of the Sagzabad Cluster, central Iran: Human-induced deposition on an arid alluvial plain // Quaternary International. 2014. Vol.324. P. 67-83; Sedov S. N., Aleksandrovskii A. L., Shishkov V. A. et al. Anthropogenic Sediments and Soils of Tells of the Balkans and Anatolia: Composition, Genesis, and Relationships with the History of Landscape and Human Occupation // Eurasian Soil Science. 2017. Vol. 50 (4). P.373-386. 
another reason, ideally (from the perspective of archaeology) due to a natural catastrophe leading to instant archaeologisation of the source (the usual example of such event is the burial of cities of Pompeii and Herculaneum by the thickness of pyroclastic deposits, but there may be other types of instant interment by mudflows, landslides or tsunamis).

Such an event will result in the formation of a single massive "cultural layer", often with a number of sub-horizons separated by clear lithostratigraphic markers (yet it may also have either zero or a limited number of such markers). The accumulation period of this "layer" obviously may cover hundreds or first thousands of years, and thus it appears to be a palimpsest formed by human activity carried out in a particular area of the earth surface. Such approach never provokes doubts in the majority of archaeological topics but becomes controversial when applied to the Stone Age archaeology, especially the Palaeolithic, where it competes with other interpretative models ${ }^{7}$.

The above "classic" formulation of the "cultural layer" concept is quite dubious on its own as it implies a certain original specificity of such deposits, which casually determines (combined with the widespread use of the term "settlement" for the Stone Age sites) the idea of the relative brevity of the human activity episode which resulted in the formation of "cultural layer". In other words, this definition creates a logical trap predetermining the interpretation of the evidence/facts observed in the horizon as "mostly artificial", with human activity seen as an agent for the formation of such. This is undoubtedly an illusion stemming from the period when the conceptual apparatus of our science was formed before the emergence of methods for the objective control of the age of sediments (radiometric and dosimetric methods of dating) and on the basis of the analysis of relatively recent but thick deposits of archaeological sites from the historical time which included large cultural remains (e. g. remains of buildings and their footings as well as other objects), and various anthropo-/technogenic sediments, whose volume of in locations of human settlements increased virtually exponentially with the geological time.

The research has shown that the "cultural layers" of archaeological sites are rather diverse. Indeed, in some cases it can be assumed that these are man-made formations. And, in this case, how to deal with the horizon formed in the distant past as a result of the re-deposition of the material? Does or does not a bone horizon (for example, deposits of the so-called mammoth "graveyards"), definitely man-made but devoid (completely or almost entirely) of formal artefacts, represent the cultural layer?

\section{The mechanism of formation of the deposits containing archaeological materials}

Mammoths never buried their relatives, and thereby did not arrange "cemeteries", while a man, as opposed to water and wind, has never been the agent for the lithogenesis of sedimentary rocks resulting in formation of all loose sediments on Earth. This position is fundamental, and it does not allow exceptions. In this regard, it would be fair to consider the problem of formation of horizons containing evidence of past human activity within the same framework. Lithogenesis is a combination of natural processes of formation

7 See, for instance: Malinsky-Buller A., Hovers E., Marder O. Making time: "Living floors", "palimpsests" and site formation processes - A perspective from the open-air Lower Paleolithic site of Revadim Quarry, Israel // Journal of Anthropological Archaeology. 2011. Vol.30. P. 89-101. 
and subsequent transformations of sediments, the main factors of which being tectonic movements and climate. Five main phases of lithogenesis have been distinguished, the first three of which are the most significant from the perspective of Quaternary geology and archaeology: weathering of rocks, denudation (including the transfer of the source material of deposits) and sedimentation (sedimentogenesis), which result in accumulation of loose sedimentary material not yet turned into sedimentary rock.

One of the founders of the lithogenesis theory, Soviet geologist N. M. Strakhov ${ }^{8}$ identified three main types of the lithogenesis (glacial/nival, humid, arid) with strongly pronounced geographic (climatic) zonation, and one intrazonal (volcanogenic, extremely rarely contributing to the formation of culture-bearing deposits). Currently, the cryogenic type of lithogenesis, or cryolithogenesis, is being distinguished as a specific process, typical for cryolithozone, including the regions of its presence in the past ${ }^{9}$. This is related to the fact that in cryolithogenesis, at all stages of sedimentary rock formation, factors and processes of lithogenesis are characterised by clear qualitative differences (low temperatures, cementation of loose deposits by ice, cyclic processes of permafrost growth, and degradation), and, as a result, they determine the formation of deposits produced by exclusively cryogenic type of lithogenesis ${ }^{10}$.

In most cases, water, wind, and gravitation become agents for the formation of sediments (i.e. of sedimento- and lithogenesis) bearing cultural remains; only in rare cases, the determining agent for their formation is human activity leading to creation of massive deposits of long-term settlements and towns, or to transformation of a part of deposits which form a habitat surface within a specific area. Thus, culture-bearing deposits of Chukchi and Eskimo sites ${ }^{11}$, accumulated for roughly 2000 years, whose thickness reaches first meters, were developed not just by the deposition of sediments but rather by multi-occasion building of submerged structures/huts within a limited area. This construction activity was continuous for sanitary reasons as each such structure, being long-term, relatively quickly would have become unusable because of "dirt and stench" associated with its long exploitation ${ }^{12}$.

Most often, the burial/archaeologisation of any type of cultural remains results from the accumulation (the final deposition) of sediments in the process of sedimentogenesis, i.e., enrichment of these deposits with evidence of the past human activity. As such, the most important characteristic of a lithological horizon bearing cultural remains is the sediment type, its mechanical composition, and the accumulation conditions. This idea is clearly highlighted in the so-called geoarchaeological approach ${ }^{13}$, which is believed to have come to us from the West, although it has century-long history in the national

8 Strakhov N. M. Tipy litogeneza i ikh evoliutsiia v istorii Zemli. Moscow, 1963. P. 5-7.

9 Romanovskii N.N. Osnovy kriogeneza litosfery. Moscow, 1993. P.5-7; Ershov E.D. Obshchaia geokriologiia. Moscow, 2002. P. 6-12.

${ }^{10}$ Ershov E. D. Obshchaia geokriologiia. P. 475-481.

11 See, for example: Rudenko S.I. Drevniaia kul'tura Beringova moria i eskimosskaia problema. Moscow; Leningrad, 1947. P. 33, 35, 41, 43; Dikov N. N. Arkheologicheskie pamiatniki Kamchatki, Chukotki i Verkhnei Kolymy (Aziia na styke s Amerikoi v drevnosti). Moscow, 1977. P. 156-205.

12 Bogoraz V. G. Chukchi. Material'naia kul'tura. Moscow, 2011. P. 111-112.

13 See, for example: Waters M. R. Principals of Geoarchaeology: A North American Perspective. Tucson, 1992; Rapp G., Hill C. L. Geoarcheology. The Earth-Science Approach to Archaeological Interpretation. New Haven and London, 1998; Kuzmin Y. V. Geoarkheologiia: estestvennonauchnye metody v arkheologicheskikh issledovaniiakh. Tomsk, 2017. 
Russian traditions being known since the times of A. I. Inostrantsev and I. D. Cherskiy ${ }^{14}$. De-facto, it has been widely used in Russian archaeological research, primarily in the most remarkable projects of the last twenty years ${ }^{15}$.

As a result of this and other researches, a clear understanding of the ambiguity of the object of study has emerged - with, on the one hand, undeniable anthropogenic constitute within it, and, on the other - a natural component. That is why N. B. Leonova ${ }^{16}$ and colleagues determine it as a natural-anthropogenic object, "junk of centuries, a deposit created by humans in the site of their habitation, with contribution of natural processes"; the natural component of the cultural layer is being considered as a particular substrate formed from soil horizon and (or) a lithological layer in the place of which the layer was formed. Similar, yet less romantic definition has been proposed by V.I. Belyaeva ${ }^{17}$, who, based on her own long research experience, suggests that "it would be useful to apply the neutral term to the layer with cultural remains such as, let's say, anthropogenic layer" as it is possible to define in this way "any stratigraphic horizon to whose specific layer any cultural remains of the Palaeolithic are related".

A similar idea has been put forward by A. P. Derevyanko ${ }^{18}$ who highlights that despite the widely spread perception, the cultural layer is not the remains of an ancient settlement, "covered by soil", but it represents a sophisticated geological formation which has appeared as a result of joint activity of anthropogenic and natural factors and has undergone major post-depositional changes, and, as such, the genesis of a cultural layer is a composite process, at each stage of which cultural remains have been affected by a specific set of destructive factors. It follows that the level of the initial undisturbance of the material is somewhat conditional even in the situation of presence of the indisputable geological context in situ. Therefore, the consensus in understanding of the mechanism of development of "cultural layers" is obvious. In A. P. Derevyanko's perception" ${ }^{19}$, the semantics of the term "cultural layer" in Palaeolithic studies differs from that adopted in archaeology of the later periods but it would be more accurate to speak of the differences between these entities accepting that the mechanisms driving them are uniform - if the concept of the "cultural layer" is universal, the mechanism of its formation should be universal. It only needs to be

${ }^{14}$ Medvedev G. I. Geoarkheologiia. Siuzhety istorii formirovaniia // Antropogen: paleoantropologiia, geoarkheologiia, etnologiia Azii. Irkutsk, 2008. P. 133-155.

15 See e. g.: Velichko A.A., Grekhova L.V., Gribchenko Y.N., Kurenkova E.I. Pervobytnyi chelovek v ekstremal'nykh usloviiakh sredy. Stoianka Eliseevichi. Moscow, 1997; Amirkhanov H. A. Zaraiskaia stoianka. Moscow, 2000; Issledovaniia paleolita v Zaraiske. 1999-2005 / ed. by H. A. Amirkanov. Moscow, 2009; Amirkhanov H. A., Lev S. Y., Seleznev A. B. Problema "paleoliticheskoi derevni" kostenkovskoi kul'tury v svete issledovanii Zaraiskoi stoianki // Kratkie soobshcheniia IA RAN.2001. Iss. 211. P.5-16; Belyaeva V.I. Paleoliticheskaia stoianka Pushkari I (kharakteristika kul'turnogo sloia). St. Petersburg, 2002; Derevianko A.P., Shunkov M. V., Agadzanyan A.K. et al. Prirodnaia sreda i chelovek v paleolite Gornogo Altaia. Novosibirsk, 2003; Leonova N.B., Nesmeyanov S. A., Vinogradova E. A. et al. Paleoekologiia ravninnogo paleolita. Moscow, 2006; Aleksandrovskii A. L. Kul'turnyi Sloi: Genezis, Geografiia, Sistematika, Paleoekologicheskoe Znachenie // Arkheologiia i estestvennye nauki v izuchenii kul'turnogo sloia ob’ektov arkheologicheskogo naslediia. Moscow, 2018. P. 7-16.

${ }^{16}$ Leonova N.B., Sycheva S.A., Uzyanov A.A. et al. Rukovodstvo po izucheniiu paleoekologii kul'turnykh sloev drevnikh poselenii (polevye issledovaniia: skhema opisaniia i otbor obraztsov). Moscow, 1998; Leonova N. B., Nesmeyanov S. A., Vinogradova E. A. et al. Paleoekologiia ravninnogo paleolita. P. 32-34.

17 Belyaeva V.I. Paleoliticheskaia stoianka Pushkari I (kharakteristika kul'turnogo sloia). P. 39-40.

18 Derevianko A.P., Markin S. V., Vasiliev S. A. Paleolitovedenie: Vvedenie i osnovy. Novosibirsk, 1994. P. 68-70.

19 Ibid. P. 69. 
formulated taking into account the characteristics of geoarchaeological approach to the study of the Stone Age sites.

Noteworthy, the concept of "cultural layer" does not appear even in the subject index of the geoarchaeology manuals ${ }^{20}$. This seeming strangeness is more than outweighed by the concept of primary archaeological context, i. e., evidence found in situ. This is where the fundamental difference between the "traditional" and "geoarchaeological" approach is hidden - if in the first case the researcher accepts in advance the artificiality of the observed facts (and very rarely agrees to an alternative interpretation), in the second one the most important part is the study of taphonomy of cultural remains (in any form artefacts, structures, etc.) in order to find the evidence of the "artificiality" setting the limitations that should be applied to the interpretation of the source ${ }^{21}$. In other words, this is a normal process of critique of the source, absolutely similar to the one taking place in the Palaeolithic studies (and in archaeology in general) at the stage of recognition of the man-made nature of this or another object.

The majority of problematic interpretations seem to owe their origin to an attempt of reconstruction of the event, which is undoubtedly related to the research philosophy based on the perception of archaeology as part of historical science, only "armed with a shovel", according to the widely known apocryphal expression. Unfortunately, the resolution of the method outside the limits of archaeology of the written period (i.e. history itself) does not allow this (except for the cases of study of burials and hoards, i. e. closed complexes), but in return it gives an opportunity to reconstruct various processes that took place in the past: the evolution of culture (primarily material) and technology, economic processes and behaviour of human populations as a result of the totality of events of the past. Careful study of geology and palaeogeography of sites also allows seeing and reconstructing the procedures of space management, specific for different periods ${ }^{22}$, and

20 See e.g.: Waters M. R. Principals of Geoarchaeology. P. 389-398; Rapp G., Hill C. L. Geoarcheology. P. 255-274.

${ }^{21}$ See, for example: Amirkhanov H. A., Lev S. Y., Seleznev A.B. Problema "paleoliticheskoi derevni”... P.5-16; Anderson K. L., Burke A. Refining the definition of cultural levels at Karabi Tamchin: a quantitative approach to vertical intra-site spatial analysis // Journal of Archaeological Science. 2008. Vol.35. P. 2274-2285; Leonova N. B. Dlitel'nost' obitaniia na verkhnepaleoliticheskikh stoiankakh // Problemy paleoekologii drevnikh obshchestv. Moscow, 1993. P. 74-97; Leonova N. B., Nesmeyanov S. A. Problemy paleoekologicheskoi kharakteristiki kul'turnykh sloev // Metody rekonstruktsii v arkheologii. Novosibirsk, 1991. P. 219-246; Leonova N. B., Vinogradova E. A. Mikrostratigrafiia kul'turnogo sloia. Vozmozhnosti interpretatsii // Problemy kamennogo veka Russkoi ravniny. Moscow, 2004. P. 157-174; Kontogiorgos D. Non-Linear Spatial Patterning in Cultural Site Formation Processes - The Evidence from Micro-Artefacts in Cores from a Neolithic Tell Site in Greece // Applications of Self-Organizing Maps. London, doi 10.5772/51193; Machado J., Hernández C. M., Mallol C., Galván B. Lithic production, site formation and Middle Palaeolithic palimpsest analysis: in search of human occupation episodes at Abric del Pastor Stratigraphic Unit IV (Alicante, Spain) // Journal of Archaeological Science. 2013. Vol. 40. P. 2254-2273; Macphail R. L. Site formation processes in archaeology: Soil and sediment micromorphology // Quaternary International. 2013. Vol.315. P. 1-2; Macphail R. I., Bill J., Crowther J. et al. European ancient settlements - A guide to their composition and morphology based on soil micromorphology and associated geoarchaeological techniques; introducing the contrasting sites of Chalcolithic Bordus, ani-Popină, Borcea River, Romania and Viking Age Heimdaljordet, Vestfold, Norway // Quaternary International. 2017. Vol.460. P.30-47; Madgwick R., Mulville J. Reconstructing depositional histories through bone taphonomy: extending the potential of faunal data // Journal of Archaeological Science. 2015. Vol.53. P.255-263; Pitulko V. V., Pavlova E. Y. Geoarchaeology and Radiocarbon Chronology of Stone Age Northeast Asia. College Station, 2016. P. XIV-XV.

${ }^{22}$ Delhon C., Thiébault S., Berger J.-F. Environment and landscape management during the Middle Neolithic in Southern France: Evidence for agro-sylvo-pastoral systems in the Middle Rhone Valley 
understanding the causes of their variability as a response to the impact of the main external controlling factor - evolution of the habitat.

An essential element of geoarchaeological research is the study of post-depositional processes which substantially contribute to the transformation of horizons with archaeological material ${ }^{23}$. It is often and erroneously believed that these phenomena are most common in mountainous countries or in the regions of distribution of permafrost rocks, where they are associated with different stages of cryogenesis. Yet, it should be borne in mind that in the area of the past presence of cryolitozone, such processes had a significant impact on the structure of the thickness of loose deposits during the degradation of permafrost. Furthermore, even the areas, which never saw permafrost, fully manifest massive flat denudation, solifluctional, defluctional (centuries-long movement, or creep, including cryogenic), suffosional and other processes expressed geomorphologically and causing corresponding structural changes in the sediments they process, so-called complex denudation characteristic of the slopes of valleys and ravine drainage systems ${ }^{24}$.

As such, for example, solifluction (viscoplastic current of water-logged soil), widely represented in cryolithozone, appears everywhere (including tropical climates); for its development, sufficient conditions include the presence of fine soils, seasonal freezing of sediments (or other case of super water-saturated deposits) and a slope of at least $2^{\circ}$ (the movement of the particles by gravity is already possible at such angle). The speed of the process varies depending on the slope angle, integrity of the sod cover, and mechanical composition of deposits. Slow, fast and rapid types of solifluction have been distinguished. The most widespread is slow solifluction, which appears as a viscoplastic flow of deposits

// Quaternary International. 2009. Vol.200. P. 50-65; Grøn O. A Siberian perspective on the north European Hamburgian Culture: a study in applied hunter-gatherer ethnoarchaeology // Before Farming. 2005. No. 1 (3). P. 1-30; Guo Y., Mo D., Mao L. et al. Settlement distribution and its relationship with environmental changes from the Paleolithic to Shang-Zhou period in Liyang Plain, China // Quaternary International. 2014. Vol.321. P.29-36; Leonova N. B., Vinogradova E. A., Nesmeyanov S. A., Voeikova O.A. Organizatsiia proizvodstvennoi deiatel'nosti i ispol'zovanie osobennostei mikrorel'efa na stoianke Kamennaia balka II (verkhnii paleolit) // Pervobytnye drevnosti Evrazii: k 60-letiiu Alekseia Nikolaevicha Sorokina. Moscow, 2012. P. 179-192; McNeil C. L. Deforestation, agroforestry, and sustainable land management practices among the Classic period Maya // Quaternary International. 2012. Vol.249. P. 19-30; Otte M. The management of space during the Paleolithic // Quaternary International. 2012. Vol.247. P.212-229.

${ }^{23}$ See, for example: Pitulko V. V.: 1) The Zhokhov Island Site and Ancient Habitation in the Arctic. Vancouver, 2013; 2) Chapter 16. Digging through permafrost in Siberia // Field Archaeology from Around the World. Ideas and Approaches. Heidelberg, New York, Dordrecht, London, 2015. P.111-113; 3) Permafrost Digging // Encyclopedia of Global Archaeology. Cham, Springer, 2019. P. 1-29; Pitulko V. V., Pavlova E. Y.: 1) Permafrost as an Archaeological Environment. Geomorphic Processes and Geoarchaeology: from Landscape Archaeology to Archaeotourism. Moscow; Smolensk, 2012. P.224-227; 2) Opyt radiouglerodnogo datirovaniia kul'turosoderzhashchikh otlozhenii Zhokhovskoi stoianki (Novosibirskie o-va, Sibirskaia Arktika) // Zapiski IIMK RAN. 2015. No. 12. P. 27-55; 3) Geoarchaeology and Radiocarbon Chronology of Stone Age Northeast Asia. P.7-58, 91-94; Todisco D., Bhiry N., Desrosiers P. M. Paleoeskimo Site Taphonomy: An Assessment of the Integrity of the Tayara Site, Qikirtaq Island, Nunavik, Canada // Geoarchaeology. 2009. Vol.24. P. 743-791; Todisco D., Bhiry N. Palaeoeskimo Site Burial by Solifluction: Periglacial Geoarchaeology of the Tayara Site (KbFk-7), Qikirtaq Island, Nunavik (Canada) // Geoarchaeology. 2008. Vol.23. P.177-211; Zolnikov I.D., Deev E. V., Slavinskiy V.S. et al. Geologicheskoe stroenie i postsedimentatsionnye deformatsii arkheologicheskogo pamiatnika Afontova gora-II (g. Krasnoiarsk, Sibir') // Russian Geology and Geophysics. 2017. Vol. 58 (2). P. 231-242.

${ }^{24}$ Boch S. G. Nabliudeniia nad formami mikro- i mezorel'efa v chetvertichnykh otlozheniiakh, sviazannykh s merzlotnymi protsessami // Metodicheskoe rukovodstvo po izucheniiu i geologicheskoi s"emke chetvertichnykh otlozhenii: in 2 vols. Vol.2. Moscow, 1955. P.298-345; Chemekov Y. F., Ganeshin G.S., Solovyov V. V. et al. Metodicheskoe rukovodstvo po geomorfologicheskim issledovaniiam. Leningrad, 1972. 
developed on relatively flat slopes up to $15^{\circ}$, with a speed from several to tens centimetres a year. Due to the relatively uniform and constant flow of the process, slow solifluction has no specific morphological result; such slopes are characterized by smooth surface. Even lower speeds are observed in the centuries-long movement of the ground (defluction). However, it is important that in the absence of external features these processes have a significant impact on the involved sediments.

A huge contribution to the formation of the slope complex deposits is made by the processes of sheet washing, which forms deluvial deposits. Its intensity depends on several factors: the steepness and length of the slope and the composition of its sediments; atmospheric precipitation regime; the intensity of spring snowmelt; the micro-relief and the nature of the slope surface. However, the presence or absence of sod on the slope affects the intensity of deluvial washing more than any of these factors. In the case of unclosed or disturbed land cover, it can go very intensively even at a low slope angle of $2-3^{\circ}$ only. The energy of the flow of rain or melt waters in the form of thin interlacing currents, covering the entire surface of the slopes with their thick net, is very low, yet even they are able to perform a considerable amount of work. Thus, at the Desna ravine model station ${ }^{25}$, on the plowed field and on the oat and corn plantations, at the slope of $17^{\circ}$, precipitation intensity of $2 \mathrm{~mm} / \mathrm{min}$ and their total deposit of $120 \mathrm{~mm}$ (for a single rainfall), the washout reached $47 \mathrm{t} / \mathrm{ha}$, i. e. averaged to $4.7 \mathrm{~kg} / \mathrm{m}^{2}$.

The arrival of significant volumes of material leads to the rapid accumulation of sediments which bury cultural remains deposited on the ancient living surface. These are the processes developed in the Upper Palaeolithic sites of the East European Plain. In combination with fossil cryogenesis ${ }^{26}$, they have made a significant contribution to the post-depositional processing of horizons with archaeological materials.

Finally, the tectonic regime of the territories plays an important role in the formation of loose sediments containing evidence of past human activity. In areas that tend to upheave, denudation processes are more active. In such conditions, the prevalence of denudation over accumulation in most cases prevents the formation of deposits in which cultural remains would be buried quickly enough. Thus, a large part of the northeastern Siberia is taken by four newest orogenic regions - Yana-Kolyma, Okhotsk-Chukotka, Tauy-Anadyr, and Koryak - in which elevation speed reaches 3-5 mm/year ${ }^{27}$. Therefore, surface and sub-surface archaeological contexts are common in this area, making up more than $90 \%$ of all Stone Age archaeological sites in the region ${ }^{28}$.

However, in platform areas with a calm tectonic regime, in elevations, local denudation processes can be much more active as well. A small thickness of overlapping sediments in a number of Palaeolithic sites located in the area of Voronezh anteclise in the

25 Leontiev O. K., Rychagov G. I. Obshchaia geomorfologiia. Moscow, 1979. P. 126-127.

${ }^{26}$ Velichko A. A. Paleoklimaty i paleolandshafty vnetropicheskogo prostranstva Severnogo polushariia. Pozdnii pleistotsen - golotsen. Moscow, 2009; Vandenberghe J., French H. M., Gorbunov A. et al. The Last Permafrost Maximum (LPM) map of the Northern Hemisphere: permafrost extent and mean annual air temperatures, 25-17 ka BP // Boreas. 2014. Vol.43. P. 652-666.

27 Smirnov V.N. Severo-Vostok Evrazii // Noveishaia tektonika, geodinamika i seismichnost' Severnoi Evrazii. Moscow, 2000. P. 120-133.

${ }^{28}$ Dikov N. N. Arkheologicheskie pamiatniki Kamchatki, Chukotki i Verkhnei Kolymy (Aziia na styke s Amerikoi v drevnosti). P. 119-153; Slobodin S. B. Arkheologiia Kolymy i Kontinental'nogo Priokhot'ia v pozdnem pleistotsene i rannem golotsene. Magadan, 1999. P. 36-153. 
centre of the East European Plain (East-European Platform) can probably be associated with this.

The geoarchaeological approach appears to be very productive also due to the fact that it drastically reduces the number of possible frustrations that often lead researchers to hold on to unintentionally created myths, the justification of which lies in the seemingly artificial origin of the reconstructed objects, structures, spatial relationship of the evidence of past human activity observed during excavations. Significant in this regard is the history of the "blindage-like dwelling structures" distinguished in the Palaeolithic of the Russian Plain by V.A. Gorodtsov ${ }^{29}$. A. A. Velichko ${ }^{30}$ demonstrated that the researcher described as dwelling structures large pseudomorphs (ice-wedge casts) formed due to degradation of the ice-wedges, in the backfill of which there was archaeological material from the above-lying cultural horizon. Equally typical examples of such mythology are, among other things, well-known in the Upper Palaeolithic sites of the Russian Plain structures of mammoth bones interpreted as the evidence of building of dwelling structures, the concerns about the purpose of which (but not about the fact of their man-made origin) are rather justified ${ }^{31}$.

In terms of the distribution of mammoth bone remains, whose clusters change their configuration according to the slope, one can see in some cases the manifestation of the past solifluction processes, which transformed the outlines of the originally artificial (anthropogenic) context created on the living surface. Thus, their lower areas down the slope often have characteristic arch-shaped outline, taking the form of the final festoon of the solifluction tongue. It is possible to imagine the scale of this impact, in particular, from the results of an experiment set up by the Upper Palaeolithic researchers in France in order to assess the contribution of low-speed solifluction processes to the areal distribution of the material and the variability of the configuration of the initial distribution area of the remains. It was found that in just 20 years both of the analysed indicators had changed quite significantly ${ }^{32}$. At the same time, the "sedimentological-palaeozoological concept of origin of mammoth graveyards" proposed by Y. A. Lavrushin ${ }^{33}-$ simply put, the hypothesis about the mudflow origin of large concentrations of bone remains - is completely incompatible with these facts.

Finally, it should be mentioned that geoarchaeological approach is not exclusively reserved for the Stone Age archaeology, where it is undoubtedly most demanded. Principles and methods borrowed from a wide range of Earth sciences are efficient in solving

29 Gorodtsov V.A. Timonovskaia paleoliticheskaia stoianka. Rezul'taty arkheologicheskikh raskopok v 1933 g. Moscow; Leningrad, 1935; Krainov D. A. Zhilishcha Timonovskoi paleoliticheskoi stoianki (po raskopkam V. A. Gorodtsova) // Soviet Archaeology. 1956. Vol. XXV. P. 13-34.

30 Velichko A. A., Grekhova L. V., Gubonina Z. P. Sreda obitaniia pervobytnogo cheloveka Timonovskikh stoianok. Moscow, 1977. P.47-53; Velichko A.A., Grekhova L.V., Gribchenko Y.N., Kurenkova E.I. Pervobytnyi chelovek v ekstremal'nykh usloviiakh sredy. P. 51-63.

31 Gavrilov K. N. "Zhilishcha" anosovsko-mezinskogo tipa: proiskhozhdenie i interpretatsiia // Stratum plus. 2015. No. 1. P. 187-204.

32 Lenoble A., Bertran P., Lacrampe F. Solifluction-induced modifications of archaeological levels: simulation based on experimental data from a modern periglacial slope and application to French Palaeolithic sites // Journal of Archaeological Science. 2008. Vol.35. P. 99-110.

33 Lavrushin Y. A., Bessudnov A. N., Spiridonova E. A. et al. Paleozoologicheskie katastrofy v pozdnem paleolite tsentra Vostochnoi Evropy (osnovy sedimentologo-paleozoologicheskoi kontseptsii vozniknoveniia kladbishch mamontov). Moscow, 2015. 
research problems in absolutely any aspects of archaeology and regions ${ }^{34}$. In a broader sense, geoarchaeology is perceived as a complex palaeogeographic approach ${ }^{35}$, routine in modern research.

\section{Definition of the term}

It appears that for the aforementioned and other cases (with the exception of burial complexes and structures), the concept of culture-bearing sediments, which represent a specific geological formation, will be much more universal. The specificity of such formations is determined by the fact of the presence of traces of human activity in them, in one form or another, which allows for their classification on these grounds ${ }^{36}$. In particular, there may be those with indisputable proof of human presence among them - for example, in the form of evidence of hunting contact ${ }^{37}$ or butchery ${ }^{38}$, where any artefacts are absent.

Thus, culture-bearing deposits represent sediments enriched with traces of past human activity (artefacts, technological waste, biological remains, structures, i. e. cultural remains sensu lato) as a result of the transfer and accumulation of matter in the process of lithogenesis of sedimentary rocks. Since their primary accumulation occurs in subaerial conditions, soil formation process usually plays an important role in the formation of culture-bearing horizons ${ }^{39}$. This formation represents cultural layer sensu stricto as an element of the cross-section with stratigraphic expression and specific composition, which distinguishes it from the underlying and overlying sediments. Secondary contexts are formed as a result of the transformation of original culture-bearing deposits due to a deep processing of the enclosing rocks by post-depositional processes, erosion, denudation.

34 Allen M.S., Morrison A.E. Modelling site formation dynamics: geoarchaeological, chronometric and statistical approaches to a stratified rockshelter sequence, Polynesia // Journal of Archaeological Science. 2013. Vol. 40. P. 4560-4575; Milek K. B., Roberts H. M. Integrated geoarchaeological methods for the determination of site activity areas: a study of a Viking Age house in Reykjavik, Iceland // Ibid. P. 1845-1865; Lisá L., Komoróczy B., Vlach M. et al. How were the ditches filled? Sedimentological and micromorphological classification of formation processes within graben-like archaeological objects // Quaternary International. 2015. Vol.370. P. 66-76.

35 Fouache E. What is Geoarchaeology? // Geodinamica Acta. 2007. Vol. 20 (5). P. I-II.

${ }^{36}$ Medvedev G. I., Nesmeyanov S. A. Klassifikatsiia kul'turosoderzhashchikh otlozhenii // Metodologicheskie problemy arkheologii Sibiri. Novosibirsk, 1988. P. 45-55.

37 Nikolskiy P., Pitulko V. Evidence from the Yana Palaeolithic site, Arctic Siberia, yields clues to the riddle of mammoth hunting // Journal of Archaeological Science. 2013. Vol. 40. P. 4189-4197; Pitulko V. V., Basilyan A. E., Pavlova E. Y. Massovye skopleniia kostnykh ostatkov mamontov s priznakami deiatel'nosti drevnego cheloveka (r. Ilin-Syalakh, sever Iano-Indigirskoi nizmennosti) // Zapiski IIMK RAN. 2013. No. 8. P.34-52; Pitulko V. V., Pavlova E. Y., Basilyan A.E. Mass accumulations of mammoth (mammoth 'graveyards') with indications of past human activity in the northern Yana-Indighirka lowland, Arctic Siberia // Quaternary International. 2016. Vol.406. P.202-217; Pitulko V. V., Tikhonov A. N., Pavlova E. Y. et al. Early human presence in the Arctic: evidence from 45,000-year-old mammoth remains // Science. 2016. Vol.351. P. 260-263.

38 Kenady S.M., Wilson M.C., Schalk R.F., Mierendorf R.R. Late Pleistocene butchered Bison antiquus from Ayer Pond, Orcas Island, Pacific Northwest: Age confirmation and taphonomy // Quaternary International. 2011. Vol.233. P. 130-141.

39 See, for example: Leonova N.B., Sycheva S.A., Uzyanov A. A. et al. Rukovodstvo po izucheniiu paleoekologii... P. 25-27; Sycheva S. A. Pochvenno-geomorfologicheskie aspekty formirovaniia kul'turnogo sloia drevnikh poselenii // Eurasian Soil Science. 1994. No. 3. P.28-33. 
It should be emphasized that the bone-bearing horizons, rather ill-termed "graveyard" after N.K. Vereschagin ${ }^{40}$, are often or almost always anthropogenic in their origin ${ }^{41}$, and on this basis their sediments must be considered as cultural horizon. The cultural horizons of peatland sites are just as different from the "regular" archaeological context, but this does not prevent them from being perceived as evidence of past human activity. Similar to any other culture-bearing accumulations, such deposits are subject to repeated transformations, washouts, re-depositions, and become a secondary context that preserves the evidence of anthropogenic origin, in one way or another ${ }^{42}$.

Cultural remains, which are included in sediments formed on a particular surface, may represent a primary context (i.e., essentially preserving the original position and spatial relation) deposited on an ancient day surface (the occupation surface). However, even in this case, for a relatively long time, such deposits represent an open dynamic system, in which material of a different but age-related episode of human activity, stratigraphically indistinguishable, can be added, and such events may be somewhat repetitive. As a result, a palimpsest emerges, organized both in thickness and in span of the culture-bearing horizon, within which in some cases, based on micro-stratigraphic and other grounds, it is possible to distinguish relatively simultaneous habitat areas ${ }^{43}$.

Due to the restrictions imposed by the dating method, the actual number of such events will forever remain unknown, and for this reason opposing the "living floor" (resulting from a one-off event) and "palimpsest" 44 does not make sense as it is usually impossible to firmly prove the single occurrence of the event, and the concept of "one-off inhabiting" immediately ceases to accept dates beyond reasonable (from the researcher's point of view) length of residing of an ancient person in the site; illusory interpretations of the structures discovered during the excavations begin to be put forward. At the same time, for archaeological sites whose cultural remains are comprised in the slope complex deposits, there is a chance that in the buried condition there will be a "living platform"

40 Vereschagin N.K. O proiskhozhdenii mamontovykh kladbishch // Prirodnye obstanovki i fauny proshlogo. 1972. No. 6. P.131-148.

41 Basilyan A.E., Anisimov M.A., Nikolskiy P.A., Pitulko V.V. Wooly mammoth mass accumulation next to the Paleolithic Yana RHS site, Arctic Siberia: its geology, age, and relation to past human activity // Journal of Archaeological Science. 2011. Vol.38. P.2461-2474; Kornfield M., Larson M. Bonebeds and other myths: Paleoindian to Archaic transition on North American Great Plains and Rocky Mountains // Quaternary International. 2008. Vol.191. P. 18-33; Nikolskiy P. A., Sulerzhitsky L.D., Basilyan A. E., Pitulko V. V. Prelude to the Extinction: Revision of the Achchagyi-Allaikha and Berelyokh mass accumulations of mammoth // Quaternary International. 2010. Vol.219. P. 16-25; Pitulko V.V. The Berelekh Quest: A Review of Forty Years of Research in the Mammoth Graveyard in Northeast Siberia // Geoarchaeology. 2011. Vol. 26 (1). P. 5-32; Pitulko V. V., Basilyan A. E., Pavlova E. Y. Massovye skopleniia kostnykh ostatkov... P.34-52; Pitulko V.V., Pavlova E. Y., Basilyan A.E. Mass accumulations of mammoth (mammoth 'graveyards')... P. 202-217.

42 Pitulko V.V., Pavlova E. Y., Basilyan A.E. Mass accumulations of mammoth (mammoth 'graveyards')... P. 202-217; Pitulko V. V. Permafrost Digging. P. 1-29.

${ }^{43}$ Leonova N.B., Vinogradova E. A. Mikrostratigrafiia kul'turnogo sloia. Vozmozhnosti interpretatsii. P. 157-174; Leonova N. B., Vinogradova E. A., Nesmeyanov S. A., Voeikova O. A. Organizatsiia proizvodstvennoi deiatel'nosti... P. 179-192; Gavrilov K. N. Arkheologicheskii kontekst novykh radiouglerodnykh datirovok stoianki Khotylevo 2, punkt V // Drevnie kul'tury Vostochnoi Evropy: etalonnye pamiatniki i opornye kompleksy v kontekste sovremennykh arkheologicheskikh issledovanii: Zamiatninskii sbornik. Iss. 4. St. Petersburg, 2015. P. 103-112; Pryor A. J.E., Beresford-Jones D. G., Dudin A. E. et al. The chronology and function of a new circular mammoth-bone structure at Kostenki $11 / /$ Antiquity. 2020. Vol.94 (374). P.323341.

${ }^{44}$ Malinsky-Buller A., Hovers E., Marder O. Making time. P. 89-101. 
characterizing the single episode of residing, or a set of such episodes, extremely close in time. However, reliable data on the chronometry of such deposits are needed to substantiate these conclusions.

\section{Chronometry of culture-bearing deposits}

Clearly, the time category represents the core of archaeological research. With no intention of engaging in debate with L. S. Klejn ${ }^{45}$, I would like to make few comments on this important topic, especially with regard to radiocarbon age definitions for sediments. These dates represent a multifaceted source of information ${ }^{46}$, yet in the archaeological research it is not fully used very often. They primarily provide an instrument for estimation of the age of an object, and then a variety of chronologies is created on their basis, but they are much less used in the chronometric function. In this latter case, the most often analysed are large-scale processes, such as the advance of the migration frontiers ${ }^{47}$. In some cases, sets of radiocarbon dates are studied from the perspective of reconstruction of relative population density in the past in a particular territory, and the assessment of the dynamics of human populations in time ${ }^{48}$. This approach is quite a reliable means of analysing the historical dynamics of relative numbers of certain animal species, for example, mammoths $s^{49}$, although it raises serious doubts when applied to humans ${ }^{50}$. The reason for the doubt is obvious: the dating of the osteological remains of mammoths is based on the principle "one mammoth - one date", which is followed carefully, but its compliance cannot be guaranteed when using data obtained by the dating of traces of human activity because, inevitably, the complexes left by the same group will be dated, therefore, the formed sample will have a knowing distortion which affects the reliability of the results.

In the radiocarbon dating, the sets of dates obtained for a particular culture-bearing horizon, characterizing the "length of occupation" in a specific site, are most important ${ }^{51}$.

${ }^{45}$ Klejn L. S. Vremia v arkheologii. St. Petersburg, 2015. P. 11-100.

46 Williams $A$. H. The use of summed radiocarbon probability distributions in archaeology: a review of methods // Journal of Archaeological Science. 2012. Vol.39. P. 578-589.

47 Dolukhanov P., Shukurov A., Gronenborn D. et al. The chronology of Neolithic dispersal in Central and Eastern Europe // Journal of Archaeological Science. 2005. Vol.32. P. 1441-1458; Dolukhanov P. M. Evoliutsiia prirodnoi sredy i rannee rasselenie cheloveka v Severnoi Evrazii // Put' na Sever. Okruzhaiushchaia sreda i samye rannie obitateli Arktiki i Subarktiki. Moscow, 2008. P. 33-47; Steele J. Radiocarbon dates as data: quantitative strategies for estimating colonization front speeds and event densities // Journal of Archaeological Science. 2010. Vol.37. P. 2017-2030.

48 Kuzmin Y., Keates S. Dates Are Not Just Data: Paleolithic Settlement Patterns in Siberia Derived from Radiocarbon Records // American Antiquity. 2005. Vol.70 (4). P.773-789; Kuzmin Y., Keates S. Dynamics of Siberian Paleolithic Complexes (Based on Analysis of Radiocarbon Records): The 2012 Stateof-the-Art // Radiocarbon. 2013. Vol. 55 (3). P. 1314-1321.

${ }^{49}$ Nikolskiy P. A., Sulerzhitsky L.D., Pitulko V.V. Last straw versus Blitzkrieg overkill: Climate-driven changes in the Arctic Siberia mammoth population and the Late Pleistocene extinction problem // Quaternary Science Reviews. 2011. Vol. 30. P. 2309-2328.

50 Contreras D.A., Meadows J. Summed radiocarbon calibrations as a population proxy: a critical evaluation using a realistic simulation approach // Journal of Archaeological Science. 2014. Vol.52. P.591608.

51 See, for example: Amirkhanov H. A., Lev S. Y., Seleznev A. B. Problema "paleoliticheskoi derevni".... P.5-16; Grekhova L. V. Arkheologicheskii aspekt radiouglerodnykh dat stoianok Eliseevichi // Biulleten' komissii po izucheniiu chetvertichnogo perioda. 1990. No. 59. P.111-116; Leonova N. B. Dlitel'nost' obitaniia na verkhnepaleoliticheskikh stoiankakh. P.74-97; Sokoloff D. D., Sulerzhitskiy L.D., Tutubabin V.N. Vremia aktivnosti liudei na paleoliticheskikh pamiatnikakh po dannym radiouglerodnogo datirovaniia 
Obviously, these dates do not necessarily indicate the continuous presence of humans in a particular area of the surface but indicate the returning movements of the inhabitants carried out for some reason during a remarkable time interval. The analysis of such groups of dates allows distinguishing individual episodes, or at least the main ones. In addition, dates received for a cultural horizon is the most important source of information on the chronometry of culture-bearing deposits, i.e. they enable to estimate the duration of their formation and the speed of sedimentation.

A similar work has been undertaken at Zhokhov site ${ }^{52}$ and the Yana complex of sites ${ }^{53}$. In particular, it has been demonstrated that the latter has a complicated spatial structure with functionally different sections spread over a large area, including a living zone, a zone for butchering catch and processing mammoth tusks (?), a zone for storage, preparation and initial processing of mammoth tusks.

Such zones are often termed "mammoth graveyard" but in fact they represent specific portions of the cultural layer formed by human activity ${ }^{54}$. The Yana mass accumulation of mammoth (YMAM hereafter) is a part of the site complex with exceptionally high number of mammoth osteological remains, which form undoubtedly man-made concentrations of material created with a view to subsequent using of products of hunting these animals $s^{55}$. The detected clusters of radiocarbon dates clearly indicate the synchronicity of human activity in all three sections of the complex. It is very interesting that such threepart structure has been identified for the well-known Kraków Spadzista site ${ }^{56}$, and the use of topographic depressions for organising mammoth bone depositories is typical of many Upper Palaeolithic sites in general as a part of tusk processing technology ${ }^{57}$.

The difference between the "living zone" of the complex in the Northern point of the Yana site and the mass accumulation of mammoth skeletal remains in YMAM, which

// Russian Archaeology. 2004. No. 3. P.99-102; Sulerzhitskiy L.D. Vremia sushchestvovaniia nekotorykh pozdnepaleoliticheskikh poselenii po dannym radiouglerodnogo datirovaniia kostei megafauny // Ibid. P. 103-112; Pitulko V. V., Pavlova E. Y. Kollektsii radiouglerodnykh datirovok, dlitel'nost' obitaniia liudei na stoiankakh kamennogo veka i khronometriia kul'turosoderzhashchikh otlozhenii Evraziia v kainozoe // Stratigrafiia, paleoekologiia, kul'tury. 2017. Vol. 6. P.136-143; Zaretskaya N. E., Gavrilov K. N., Panin A. V., Nechushkin R.I. Geokhronologicheskie dannye i arkheologicheskie predstavleniia o vremeni sushchestvovaniia opornykh pamiatnikov vostochnogo gravetta na Russkoi ravnine // Russian Archaeology. 2018. No. 1. P.3-16.

52 Pitulko V.V. An Early Holocene Site in the Siberian High Arctic // Arctic Anthropology. 1993. Vol. 30 (1). P. 13-21; Pitulko V. V., Pavlova E. Y. Opyt radiouglerodnogo datirovaniia... P. 27-55.

53 Pitulko V., Nikolskiy P., Basilyan A., Pavlova E. Chapter 2. Human habitation in the Arctic Western Beringia prior the LGM // Paleoamerican Odyssey. College Station, 2013. P. 13-44; Pitulko V. V., Pavlova E. Y., Nikolskiy P. A. Mammoth Ivory Technologies in the Upper Palaeolithic Arctic Siberia: a Case Study based on the materials from Yana RHS site // World Archaeology. 2015. Vol. 47 (3). P.333-389; Pitulko V. V. Uchastok Iana B Ianskoi stoianki: nekotorye nabliudeniia, sdelannye v khode raskopok 2015-2018 godov // Pervobytnaia arkheologiia. Zhurnal mezhdistsiplinarnykh issledovanii. 2019. No. 1. P. 64-91.

${ }^{54}$ Nikolskiy P., Pitulko V. Evidence from the Yana Palaeolithic site... P. 4189-4197; Pitulko V. V., Pavlova E. Y., Nikolskiy P. A. Mammoth Ivory Technologies in the Upper Palaeolithic Arctic Siberia. P. 333-389.

55 Basilyan A.E., Anisimov M. A., Nikolskiy P.A., Pitulko V.V. Wooly mammoth mass accumulation next to the Paleolithic Yana RHS site, Arctic Siberia. P.2461-2474; Nikolskiy P., Pitulko V. Evidence from the Yana Palaeolithic site... P. 4189-4197; Pitulko V., Nikolskiy P., Basilyan A., Pavlova E. Chapter 2. Human habitation in the Arctic Western Beringia prior the LGM. P. 13-44; Pitulko V. V., Pavlova E. Y., Nikolskiy P.A. Mammoth Ivory Technologies in the Upper Palaeolithic Arctic Siberia. P. 333-389.

56 Wilczyński J., Wojtal P., Sobczyk K. Spatial organization of the Gravettian mammoth hunters site at Kraków Spadzista (southern Poland) // Journal of Archaeological Science. 2012. Vol.39. P. 3627-3642.

${ }^{57}$ Nikolskiy P., Pitulko V. Evidence from the Yana Palaeolithic site... P. 4189-4197; Pitulko V. V., Pavlova E. Y., Nikolskiy P. A. Mammoth Ivory Technologies in the Upper Palaeolithic Arctic Siberia. P. 333-389. 
existed simultaneously, lies in the fact that the sedimentation in these sites happened in various conditions, so that the hosting sediments of the culture-bearing horizon belong to different genetic types, and the horizon has a different thickness and hypsometric position. Thus, if the sediments of the "living zone" accumulated in subaeral conditions with periodic return of high floodplain surface to the alluvial sedimentation zone, the sedimentation in YMAM occurred during filling of topographical lows with sediments of the deluvial-proluvial complex; therefore, the 3000 years of sedimentation at the Severniy point are "packed" in $15 \mathrm{~cm}$ of deposits, and the same interval in YMAM is represented with a thickness of about $2 \mathrm{~m}$. As such, the capacity of the culture-bearing sediments is directly related to the depositional environment.

It must be emphasized that YMAM is a rare example of this kind of formation, unlike many others preserved in situ. A range of objects of this type, studied in northeast Russia, have suffered the destructive effects of processes associated with the degradation of permafrost rocks in the late/post-glacial time. These are, for example, the localities of the Nikita Lake and Urez-22 sites $^{58}$, Ilin-Syalakh locality ${ }^{59}$, and Achchaghyi-Allaikha bonebed $^{60}$. There are still some doubts about the anthropogenic origin of the Berelekh ${ }^{61}$, but the intensive use of this object by the prehistoric humans is undeniable ${ }^{62}$.

In a broader sense, the radiocarbon age of human activity traces provides data on the chronometry of cultural deposits, i. e. allows receiving a pattern of sediment accumulation for deposits that bear cultural remains, and, based on this, estimating the mechanism, conditions and speed of accumulation of cultural material.

Thus, the series of radiocarbon dates, combined with careful study of issues related to the organization of material within the structures interpreted as "long multi-hearth dwellings" and other possible dwelling structures known both in the Russian Plain and in the Trans-Baikal region ${ }^{63}$, allow the correct understanding of the nature of such objects which represent a palimpsest. Thus, I. I. Razgildeeva ${ }^{64}$ managed to clearly demonstrate this for the "multi-hearth dwelling" in the settlement of Studenoye-2 in the Trans-Baikal region. Archaeological observations, primarily refitting, only confirmed the conclusion evident

58 Pitulko V.V., Pavlova E. Y., Basilyan A.E. Mass accumulations of mammoth (mammoth 'graveyards')... P. 202-217.

59 Pitulko V.V., Basilyan A.E., Pavlova E. Y. Massovye skopleniia kostnykh ostatkov... P. 34-52; Pitulko V., Pavlova E., Nikolskiy P. Revising the archaeological record of the Upper Pleistocene Arctic Siberia: Human dispersal and adaptations in MIS 3 and 2 // Quaternary Science Reviews. 2017. Vol. 165. P. $127-148$.

60 Nikolskiy P.A., Sulerzhitsky L.D., Basilyan A. E., Pitulko V. V. Prelude to the Extinction: Revision of the Achchagyi-Allaikha and Berelyokh mass accumulations of mammoth. P. 16-25.

61 Vereschagin N. K. Berelekhskoe "kladbishche" mamontov // Trudy Zoologicheskogo instituta. 1977. No. 72. P. 5-50.

62 Pitulko V. V. The Berelekh Quest. P.5-32; Pitulko V.V., Basilyan A.E., Pavlova E. Y. The Berelekh Mammoth Graveyard: New Chronological and Stratigraphical Data from the 2009 field season // Geoarchaeology. 2014. Vol.29. P.277-299.

63 Konstantinov A. V. Drevnie zhilishcha Zabaikal'ia (paleolit, mezolit). Novosibirsk, 2001; Rogachev A. N., Anikovich M. V. Pozdnii paleolit Russkoi ravniny i Kryma // Paleolit SSSR. Moscow, 1984. P. 162-271; Popov V. V. Kosti mamonta v konstruktsii zhilishcha anosovsko-mezinskogo tipa na stoianke Kostenki 11 (Anosovka 2) // Stratum plus. 2003-2004. No. 1. P. 157-186; Gavrilov K. N. "Zhilishcha" anosovsko-mezinskogo tipa. P. 187-204; Pryor A. J. E., Beresford-Jones D. G., Dudin A. E. et al. The chronology and function of a new circular mammoth-bone structure at Kostenki 11. P.323-341.

64 Razgildeeva I.I. Planigrafiia shestiochazhnogo kompleksa pozdnepaleoliticheskogo poseleniia Studenoe-2 v Zabaikal'e // Stratum plus. 2016. No. 1. P. 243-263. 
from the earlier dating results ${ }^{65}$, although, in the cited study, the object was traditionally considered as a single complex. With a high probability, this conclusion can be extrapolated to "multi-hearth" structures from Avdeevo (for which a large set of dates is available) ${ }^{66}$, Pushkari, as well as Kostenki.

The reason for the appearance of the pattern interpreted as a long multi-hearth structure on the living horizon is the successive transfer of the building carried out for sanitary reasons - there are ethnographical descriptions of such actions from the Chukchi ${ }^{67}$, who routinely moved the dwelling structure at the change of season. Besides, they could carry out this operation in early spring, without waiting for the regular time when the smell incompatible with life (it appears as a result of the use of the dwelling in winter as a wind protection when toileting) began to penetrate the house from the outside. In all cases, the linear relocation of the dwelling structure is predetermined by the lack of room for the new structure in the area flat enough and free of surface runoff. Typically, such areas correspond to the axis of gentle elevations in microtopography of the habitation spot. This is very relevant to objects located on the slopes and in the near-slope areas of draws. This is also characteristic of the sites of the "alluvial" Palaeolithic, which is clearly visible in the Trans-Baikal example mentioned earlier, as well as in the Yana site ${ }^{68}$.

\section{Conclusions}

The archaeological fieldwork in the Stone Age sites of northeastern Siberia suggests that cryogenic processes contribute significantly to the formation of culture-bearing deposits both during the formation and degradation of permafrost sediments, especially during the growth and destruction of the ice-wedge ice. The mechanisms of cryogenic deformations of cultural horizons and transportation of material in permafrosts have been previously described ${ }^{69}$, as well as the transformation of culture-bearing horizons as a result of melting of permafrosts, their thermodenudation, and the mechanisms of formation of secondary contexts, including those creating the illusion of archaeological multilayering of objects ${ }^{70}$.

Along with the excavated primary archaeological contexts, culture-bearing deposits comprising secondary contexts of the Late Pleistocene and Early Holocene age are wide-

${ }^{65}$ Buvit I., Terry K. Last Glacial Maximum Human Populations in the Southwest Transbaikal, Southern Siberia // From the Yenisei to the Yukon: Interpreting Lithic Assemblage Variability in Late Pleistocene/ Early Holocene Beringia. College Station, 2011. P. 47-57.

${ }^{66}$ Bulochnikova E. V. Khronologiia verkhnepaleoliticheskikh stoianok v sisteme arkheologicheskikh i estestvennonauchnykh dannykh // Khronologiia, periodizatsiia i krosskul'turnye sviazi v kamennom veke: Zamiatninskii sbornik. Iss. 1. St. Petersburg, 2008. P. 63-73.

${ }^{67}$ Bogoraz V. G. Chukchi. Material'naia kul'tura. P. 111-112.

68 Pitulko V., Nikolskiy P., Basilyan A., Pavlova E. Chapter 2. Human habitation in the Arctic Western Beringia prior the LGM. P. 13-44.

69 Pitulko V.V., Pavlova E. Y., Basilyan A.E., Kritsuk S. G. Osobennosti vertikal'nogo raspredeleniia veshchestva v kraevykh oblastiakh merzlotnykh poligonov i ego znachenie dlia datirovaniia chetvertichnykh otlozhenii kriolitozony // Materialy VII-go Vserossiiskogo soveshchaniia po izucheniiu chetvertichnogo perioda: "Kvarter vo vsem ego mnogoobrazii. Fundamental'nye problemy, itogi izucheniia i osnovnye napravleniia dal'neishikh issledovanii": in 2 vols. Vol. 2. Apatity, St. Petersburg, 2011. P. 149-153; Pitulko V. V., Pavlova E. Y. Geoarchaeology and Radiocarbon Chronology of Stone Age Northeast Asia. P. 58-109.

70 Pitulko V. V., Pavlova E. Y.: 1) Geoarchaeology and Radiocarbon Chronology of Stone Age Northeast Asia. P. 110-125; 2) Kollektsii radiouglerodnykh datirovok... P. 136-143; Pitulko V. V. Permafrost Digging. P. 25-29. 
ly presented in northeastern Siberia ${ }^{71}$. Such deposits may represent layers of materials buried in ancient times formed as a result of erosion or thermal denudation of original primary contexts. They occur in the form of concentrations of material on surface, in the form of excavated horizons - for example, in the Upstream point of the Yana site ${ }^{72}$ or the locality of Urez- $22^{73}$, as well as in the form of culture-bearing masses backfilling the icewedge casts, which is the specificity of the Zhokhov site ${ }^{74}$.

Among the Stone Age sites of northeastern Siberia, there is a quite widely represented certain type of archaeological sites - the so-called mammoth "graveyards". The oldest of these is the mass accumulation of mammoth skeletal remains ${ }^{75}$, which is a part of ca. 32,000 year old Yana complex. Other localities (Nikita Lake, Urez-22, Achchaghyi-Allaikha, Berelekh) are significantly younger, their ages range between 13,000-12,000 years old. Accumulations of mammoth bone remains are well known from other areas of Siberia, Urals, Eastern European Plain, Eastern and Central Europe. Often or nearly always archaeological sites are associated with them, or they themselves represent a part of the sites, in relation to which the researchers of the Palaeolithic repeatedly wrote about the association of archaeological sites with such objects, the exploitation of natural bone beds by prehistoric humans ${ }^{76}$. The results of the study of the Yana complex of sites ${ }^{77}$ and other "bone beds" in northeastern Siberia ${ }^{78}$ show that the majority of them are most likely objects of anthropogenic origin formed as a result of the economic activity of ancient humans in the same territory for a long time.

It should be emphasized that a large part of the territory of Russia (up to $65 \%$ ) still represents the permafrost area. The area of the past cryolitozone was much larger and included the lands that are far beyond its current borders. The culture-bearing deposits of the Late Pleistocene Stone Age sites located in these areas have undoubtedly been affected by cryogenic processes. For some of them, the signs of palaeo-cryogenesis are well

${ }^{71}$ Pitulko V. V., Pavlova E. Y., Basilyan A.E. Mass accumulations of mammoth (mammoth 'graveyards')... P. 202-217.

72 Pitulko V., Pavlova E., Nikolskiy P. Revising the archaeological record of the Upper Pleistocene Arctic Siberia. P. 127-148.

${ }^{73}$ Pitulko V.V., Pavlova E. Y., Basilyan A.E. Mass accumulations of mammoth (mammoth 'graveyards')... P. 202-217.

${ }^{74}$ Pitulko V. V. An Early Holocene Site in the Siberian High Arctic. P. 13-21; Pitulko V. V., Pavlova E. Y. Opyt radiouglerodnogo datirovaniia... P.27-55; Pitulko V. V., Ivanova V. V., Kasparov A. K. et al. Reconstructing prey selection, hunting strategy and seasonality of the early Holocene frozen site in the Siberian high Arctic: A case study on the Zhokhov site faunal remains, De Long Islands // Environmental Archaeology. 2015. Vol. 20. P. 120-157.

75 Basilyan A.E., Anisimov M.A., Nikolskiy P. A., Pitulko V.V. Wooly mammoth mass accumulation next to the Paleolithic Yana RHS site, Arctic Siberia. P. 2461-2474.

76 Anikovich M. V., Anisyutkin N. K., Platonova N. I. Chelovek i mamont v paleolite Evropy: podkhody i gipotezy // Stratum plus. 2010. No. 1. P.99-136; Vereschagin N. K. Berelekhskoe "kladbishche" mamontov. P. 5-50; Pavlov P. Y. The Paleolithic of northeastern Europe // Archaeology, Ethnology and Anthropology of Eurasia. 2008. No. 33. P. 33-45.

77 Pitulko V., Nikolskiy P., Basilyan A., Pavlova E. Chapter 2. Human habitation in the Arctic Western Beringia prior the LGM. P. 13-44; Pitulko V. V., Pavlova E. Y., Nikolskiy P. A. Mammoth Ivory Technologies in the Upper Palaeolithic Arctic Siberia. P.333-389.

78 Pitulko V.V., Basilyan A.E., Pavlova E. Y. The Berelekh Mammoth Graveyard. P.277-299; Pitulko V. V., Pavlova E. Y., Basilyan A.E. Mass accumulations of mammoth (mammoth 'graveyards')... P. 202-217; Pitulko V., Pavlova E., Nikolskiy P. Revising the archaeological record of the Upper Pleistocene Arctic Siberia. P. 127-148. 
described $^{79}$, however, its contribution to the post-depositional processes that took place at a number of archaeological sites has not been fully appreciated. Thus, the presence of permafrost conditions is the most likely reason for the lack of traces of the Palaeolithic human presence in Siberian caves. It seems that the natural data obtained during the study of the Stone Age objects of northeastern Siberia may contribute to the interpretation of the specifics of geology and stratigraphy of the Palaeolithic sites in the Eastern European Plain and beyond.

\section{References}

Akhmetgaleeva N.B. Kamennyi vek Poseim'ia: verkhnepaleoliticheskaia stoianka Byki-7. Kursk, Mechta Publ., 2015, 254 p. (In Russian)

Aleksandrovskii A.L. Kul'turnyi Sloi: Genezis, Geografiia, Sistematika, Paleoekologicheskoe Znachenie. Arkheologiia $i$ estestvennye nauki v izuchenii kul'turnogo sloia ob'ektov arkheologicheskogo naslediia. Moscow, KMK Press, 2018, pp.7-16. (In Russian)

Aleksandrovskii A. L., Boitsov I. A., Krenke N. A. Pochvy i kul'turnyi sloi Moskvy: stroenie, istoriia razvitiia, geografiia. Izvestiia Rossiiskoi Akademii Nauk, Seriia Geographicheskaia, 1997, no.4, pp.82-95. (In Russian)

Allen M.S., Morrison A.E.Modelling site formation dynamics: geoarchaeological, chronometric and statistical approaches to a stratified rockshelter sequence, Polynesia. Journal of Archaeological Science, 2013, vol. 40, pp. 4560-4575.

Amirkhanov H. A.Zaraiskaia stoianka. Moscow, Nauchnyi Mir Publ., 2000, 248 p. (In Russian)

Amirkhanov H.A., Lev S.Y., Seleznev A. B. Problema “paleoliticheskoi derevni” kostenkovskoi kul'tury v svete issledovanii Zaraiskoi stoianki. Kratkie soobshcheniia IA RAN, 2001, iss. 211, pp.5-16. (In Russian)

Anderson K. L., Burke A. Refining the definition of cultural levels at Karabi Tamchin: a quantitative approach to vertical intra-site spatial analysis. Journal of Archaeological Science, 2008, vol. 35, pp. 2274-2285.

Anikovich M. V., Anisyutkin N.K., Platonova N.I. Chelovek i mamont v paleolite Evropy: podkhody i gipotezy. Stratum plus, 2010, no. 1, pp.99-136. (In Russian).

Artsikhovskii A. V. Osnovy arkheologii. Moscow, Gospolitizdat Publ., 1955, 275 p. (In Russian)

Avdusin D. A. Polevaia arkheologiia v SSSR. Moscow, Vysshaia Shkola Publ., 1980, 335 p. (In Russian)

Basilyan A.E., Anisimov M.A., Nikolskiy P. A., Pitulko V. V. Wooly mammoth mass accumulation next to the Paleolithic Yana RHS site, Arctic Siberia: its geology, age, and relation to past human activity. Journal of Archaeological Science, 2011, vol.38, pp. 2461-2474.

Belyaeva V.I.Paleoliticheskaia stoianka Pushkari I (kharakteristika kul'turnogo sloia). St. Petersburg, St. Petersburg State University Press, 2002, 156 p. (In Russian)

Boch S. G. Nabliudeniia nad formami mikro- i mezorel'efa v chetvertichnykh otlozheniiakh, sviazannykh s merzlotnymi protsessami. Metodicheskoe rukovodstvo po izucheniiu i geologicheskoi s"emke chetvertichnykh otlozhenii, vol.2. Moscow, Gosgeoltekhizdat Publ., 1955, pp. 298-345. (In Russian)

Bogoraz V. G. Chukchi. Material'naia kul'tura. Moscow, Librocom Publ., 2011, 264 p. (In Russian)

Bulochnikova E.V.Khronologiia verkhnepaleoliticheskikh stoianok v sisteme arkheologicheskikh i estestvennonauchnykh dannykh. Khronologiia, periodizatsiia i krosskul'turnye sviazi v kamennom veke: Zamiatninskii sbornik. Iss. 1. St. Petersburg, Nauka Publ., 2008, pp.63-73. (In Russian)

Buvit I., Terry K.Last Glacial Maximum Human Populations in the Southwest Transbaikal, Southern Siberia. From the Yenisei to the Yukon: Interpreting Lithic Assemblage Variability in Late Pleistocene/ Early Holocene Beringia. College Station, Texas A\&M University Press, 2011, pp.47-57.

79 See, for example: Amirkhanov H. A., Lev S. Y., Seleznev A. B. Problema "paleoliticheskoi derevni”... P.5-16; Issledovaniia paleolita v Zaraiske. P. 15-35; Akhmetgaleeva N. B. Kamennyi vek Poseim'ia: verkhnepaleoliticheskaia stoianka Byki-7. Kursk, 2015. P.24-98; Velichko A.A., Grekhova L. V., Gubonina Z.P. Sreda obitaniia pervobytnogo cheloveka Timonovskikh stoianok. P.47-53; Velichko A. A., Grekhova L. V., Gribchenko Y.N., Kurenkova E. I. Pervobytnyi chelovek v ekstremal'nykh usloviiakh sredy. P.51-63. 
Chemekov Y. F., Ganeshin G. S., Solovyov V. V., Boitsov M. N., Seliverstov Y. P., Plotnikova M. I. Metodicheskoe rukovodstvo po geomorfologicheskim issledovaniiam. Leningrad, Nedra Publ., 1972, 384 p. (In Russian)

Contreras D. A., Meadows J.Summed radiocarbon calibrations as a population proxy: a critical evaluation using a realistic simulation approach. Journal of Archaeological Science, 2014, vol. 52, pp. 591-608.

Delhon C., Thiébault S., Berger J.-F. Environment and landscape management during the Middle Neolithic in Southern France: Evidence for agro-sylvo-pastoral systems in the Middle Rhone Valley. Quaternary International, 2009, vol. 200, pp. 50-65.

Derevianko A.P., Markin S.V., Vasiliev S.A.Paleolitovedenie: Vvedenie i osnovy. Novosibirsk, Siberian Branch of Nauka Publ., 1994, 288 p. (In Russian)

Derevianko A.P., Shunkov M. V., Agadzanyan A. K., Baryshnikov G. F., Malaeva E. M., Ulyanov V. A., Kulik N.F., Postnov A. V., Anoikin A. A.Prirodnaia sreda i chelovek v paleolite Gornogo Altaia. Novosibirsk, Institute for Archaeology and Ethnography of Siberian Branch of Russian Academy of Sciences, 2003, 448 p. (In Russian)

Dikov N. N. Arkheologicheskie pamiatniki Kamchatki, Chukotki i Verkhnei Kolymy (Aziia na styke s Amerikoi $v$ drevnosti). Moscow, Nauka Publ., 1977, 395 p. (In Russian)

Dobrovolskaia M.V., Mazhaiskii A. Y.Archaeologiia. Moscow, Moscow Pedagogical State University Press, 2012, 116 p. (In Russian)

Dolgikh A.V., Aleksandrovskii A.L. Soils and cultural layers in Velikii Novgorod. Eurasian Soil Science, 2010, no. 43, pp. 477-487.

Dolukhanov P. M. Evoliutsiia prirodnoi sredy i rannee rasselenie cheloveka v Severnoi Evrazii. Put' na Sever. Okruzhaiushchaia sreda i samye rannie obitateli Arktiki i Subarktiki. Moscow, IG RAN Press, 2008, pp. 33-47. (In Russian)

Dolukhanov P., Shukurov A., Gronenborn D., Sokoloff D., Timofeev V., Zaitseva G. The chronology of Neolithic dispersal in Central and Eastern Europe. Journal of Archaeological Science, 2005, vol.32, pp. 1441-1458.

Ershov E. D. Obshchaia geokriologiia. Moscow, Moscow Unversity Press, 2002, 682 p. (In Russian)

Fouache E. What is Geoarchaeology? Geodinamica Acta, 2007, vol. 20 (5), pp. I-II.

Gavrilov K.N. "Zhilishcha” anosovsko-mezinskogo tipa: proiskhozhdenie i interpretatsiia. Stratum plus, 2015, no. 1, pp. 187-204. (In Russian)

Gavrilov K.N.Arkheologicheskii kontekst novykh radiouglerodnykh datirovok stoianki Khotylevo 2, punkt V.Drevnie kul'tury Vostochnoi Evropy: etalonnye pamiatniki i opornye kompleksy v kontekste sovremennykh arkheologicheskikh issledovanii: Zamiatninskii sbornik. Iss. 4. St. Petersburg, Museum of Anthropology and Ethnography Publ., 2015, pp. 103-112. (In Russian)

Gorodtsov V. A. Timonovskaia paleoliticheskaia stoianka. Rezultaty arkheologicheskikh raskopok $v 1933 \mathrm{~g}$. Moscow, Leningrad, AN SSSR Press, 1935, 35 p. (In Russian)

Grekhova L. V. Arkheologicheskii aspekt radiouglerodnykh dat stoianok Eliseevichi. Biulleten' komissii po izucheniiu chetvertichnogo perioda, 1990, no. 59, pp.111-116. (In Russian)

Grøn O.A Siberian perspective on the north European Hamburgian Culture: a study in applied huntergatherer ethnoarchaeology. Before Farming, 2005, no. 1, article 3, pp.1-30.

Guo Y., Mo D., Mao L., Jin Y., Guo W., Mudie P.J.Settlement distribution and its relationship with environmental changes from the Paleolithic to Shang-Zhou period in Liyang Plain, China. Quaternary International, 2014, vol.321, pp.29-36.

Howard J.F., Ryzewski K., Dubay B.R., Killion T.W.Artifact preservation and post-depositional siteformation processes in an urban setting: A geoarchaeological study of a $19^{\text {th }}$ century neighborhood in Detroit, Michigan, USA. Journal of Archaeological Science, 2015, vol. 53, pp. 178-189.

Kenady S.M., Wilson M.C., Schalk R.F., Mierendorf R.R.Late Pleistocene butchered Bison antiquus from Ayer Pond, Orcas Island, Pacific Northwest: Age confirmation and taphonomy. Quaternary International, 2011, vol.233, pp. 130-141.

Klejn L. S. Arkheologicheskie istochniki. Leningrad, Leningrad State University, 1978, 120 p. (In Russian)

Klejn L. S. Istoriia arkheologicheskoi mysli, vol. 1. St. Petersburg, St. Petersburg University Press, 2011, 383 p. (In Russian)

Klejn L. S. Vremia v arkheologii. St. Petersburg, Eurasia Publ., 2015, 383 p. (In Russian)

Konstantinov A. V.Drevnie zhilishcha Zabaikal'ia (paleolit, mezolit). Novosibirsk, Nauka Publ., 2001, 224 p. (In Russian) 
Kontogiorgos D. Non-Linear Spatial Patterning in Cultural Site Formation Processes - The Evidence from Micro-Artefacts in Cores from a Neolithic Tell Site in Greece. Applications of Self-Organizing Maps. London, InTechOpen, 2012. https://doi.org/10.5772/51193.

Kornfield M., Larson M. Bonebeds and other myths: Paleoindian to Archaic transition on North American Great Plains and Rocky Mountains. Quaternary International, 2008, vol. 191, pp. 18-33.

Krainov D. A.Zhilishcha Timonovskoi paleoliticheskoi stoianki (po raskopkam V. A. Gorodtsova). Soviet Archaeology, 1956, vol.XXV, pp. 13-34. (In Russian)

Kuzmin Y.V.Geoarkheologiia: estestvennonauchnye metody $v$ arkheologicheskikh issledovaniiakh. Tomsk, TGU Press, 2017, 396 p. (In Russian)

Kuzmin Y., Keates S. Dates Are Not Just Data: Paleolithic Settlement Patterns in Siberia Derived from Radiocarbon Records. American Antiquity, 2005, vol. 70 (4), pp.773-789. DOI:10.2307/40035874

Kuzmin Y., Keates S. Dynamics of Siberian Paleolithic Complexes (Based on Analysis of Radiocarbon Records): The 2012 State-of-the-Art. Radiocarbon, 2013, vol. 55 (3), pp.1314-1321. DOI:10.1017/ S0033822200048220

Lavrushin Y. A., Bessudnov A. N., Spiridonova E. A., Kuralenko N. P., Nedumov R. I., Kholmovoy G. V. Paleozoologicheskie katastrofy v pozdnem paleolite tsentra Vostochnoi Evropy (osnovy sedimentologo-paleozoologicheskoi kontseptsii vozniknoveniia kladbishch mamontov). Moscow, GEOS Publ., 2015, 88 p. (In Russian)

Lenoble A., Bertran P., Lacrampe F. Solifluction-induced modifications of archaeological levels: simulation based on experimental data from a modern periglacial slope and application to French Palaeolithic sites. Journal of Archaeological Science, 2008, vol. 35, pp. 99-110.

Leonova N. B. Dlitel'nost' obitaniia na verkhnepaleoliticheskikh stoiankakh. Problemy paleoekologii drevnikh obshchestv. Moscow, Russian Open University Press, 1993, pp.74-97. (In Russian)

Leonova N.B., Nesmeyanov S. A. Problemy paleoekologicheskoi kharakteristiki kul'turnykh sloev. Metody rekonstruktsii v arkheologii. Novosibirsk, Nauka Publ., 1991, pp.219-246. (In Russian)

Leonova N.B., Nesmeyanov S.A., Vinogradova E.A., Voeikova O.A., Gvozdover M.D., Minkov E.V., Spiridonova E.A., Sycheva S. A.Paleoekologiia ravninnogo paleolita. Moscow, Nauchnyi Mir Publ., 2006, 342 p. (In Russian)

Leonova N.B., Sycheva S.A., Uzyanov A.A., Aleksandrovsky A.L., Pustovoitov K.E.Rukovodstvo po izucheniiu paleoekologii kul'turnykh sloev drevnikh poselenii (polevye issledovaniia: skhema opisaniia $i$ otbor obraztsov). Moscow, RFFI Publ., 1998, 88 p. (In Russian)

Leonova N. B., Vinogradova E. A. Mikrostratigrafiia kul'turnogo sloia. Vozmozhnosti interpretatsii. Problemy kamennogo veka Russkoi ravniny. Moscow, Nauchnyi Mir Publ., 2004, pp. 157-174. (In Russian)

Leonova N.B., Vinogradova E.A., Nesmeyanov S.A., Voeikova O.A. Organizatsiia proizvodstvennoi deiatel'nosti i ispol'zovanie osobennostei mikrorel'efa na stoianke Kamennaia balka II (verkhnii paleolit). Pervobytnye drevnosti Evrazii: k 60-letiiu Alekseia Nikolaevicha Sorokina. Moscow, IA RAN Press, 2012, pp. 179-192. (In Russian)

Leontiev O. K., Rychagov G. I. Obshchaia geomorfologiia. Moscow, Vysshaia Shkola Publ., 1979, 287 p. (In Russian)

Lisá L., Komoróczy B., Vlach M., Válek D., Bajer A., Kovárník J., Rajtár J., Hüssen C. M., Šumberová R. How were the ditches filled? Sedimentological and micromorphological classification of formation processes within graben-like archaeological objects. Quaternary International, 2015, vol. 370, pp.66-76.

Machado J., Hernández C. M., Mallol C., Galván B. Lithic production, site formation and Middle Palaeolithic palimpsest analysis: in search of human occupation episodes at Abric del Pastor Stratigraphic Unit IV (Alicante, Spain). Journal of Archaeological Science, 2013, vol. 40, pp. 2254-2273.

Macphail R. I., Bill J., Crowther J., Haită C., Linderholm J., Popovici D., Rødsrud C.L.European ancient settlements. A guide to their composition and morphology based on soil micromorphology and associated geoarchaeological techniques; introducing the contrasting sites of Chalcolithic Bordus, ani-Popină, Borcea River, Romania and Viking Age Heimdaljordet, Vestfold, Norway. Quaternary International, 2017, vol.460, pp.30-47.

Macphail R.L. Site formation processes in archaeology: Soil and sediment micromorphology. Quaternary International, 2013, vol.315, pp.1-2.

Madgwick R., Mulville J. Reconstructing depositional histories through bone taphonomy: extending the potential of faunal data. Journal of Archaeological Science, 2015, vol. 53, pp. 255-263. 
Maghsoudi M., Simpson I.A., Kourampas N., Nashli H.F. Archaeological sediments from settlement mounds of the Sagzabad Cluster, central Iran: Human-induced deposition on an arid alluvial plain. Quaternary International, 2014, vol.324, pp.67-83.

Malinsky-Buller A., Hovers E., Marder O. Making time: 'Living floors', 'palimpsests' and site formation processes - A perspective from the open-air Lower Paleolithic site of Revadim Quarry, Israel. Journal of Anthropological Archaeology, 2011, vol. 30, pp. 89-101.

Martynov A. I. Archaeologiia. Moscow, Vysshaia Shkola Publ., 2005, 447 p. (In Russian)

McNeil C.L.Deforestation, agroforestry, and sustainable land management practices among the Classic period Maya. Quaternary International, 2012, vol. 249, pp. 19-30.

Medvedev G.I.Fenomen geoarkheologicheskoi mnogosloinosti Baikal'skoi Sibiri. 100 let Baikal'skoi nauchnoi arkheologii: materialy Vserossiiskoi nauchoi konferentsii, posviashchennoi 100-letiiu so dnia otkrytiia. Irkutsk, IGU Press, 2012, pp. 5-9. (In Russian).

Medvedev G.I.Geoarkheologiia. Siuzhety istorii formirovaniia. Antropogen: paleoantropologiia, geoarkheologiia, etnologiia Azii. Irkutsk, IGU Press, 2008, pp. 133-155. (In Russian)

Medvedev G.I., Nesmeyanov S.A.Klassifikatsiia kul'turosoderzhashchikh otlozhenii. Metodologicheskie problemy arkheologii. Sibiri. Novosibirsk, Nauka Publ., 1988, pp.45-55. (In Russian).

Mier M.F., Fernández J.F., González P.A., Sáez J.A.L., Díaz S.P., Beloqui B.H.The investigation of currently inhabited villages of medieval origin: Agrarian archaeology in Asturias (Spain). Quaternary International, 2014, vol. 346, pp. 41-55.

Milek K. B., Roberts H. M. Integrated geoarchaeological methods for the determination of site activity areas: a study of a Viking Age house in Reykjavik, Iceland. Journal of Archaeological Science, 2013, vol.40, pp. 1845-1865.

Nikolskiy P.A., Sulerzhitsky L.D., Basilyan A.E., Pitulko V.V.Prelude to the Extinction: Revision of the Achchagyi-Allaikha and Berelyokh mass accumulations of mammoth. Quaternary International, 2010, vol. 219, pp. 16-25.

Nikolskiy P. A., Sulerzhitsky L. D., Pitulko V. V. Last straw versus Blitzkrieg overkill: Climate-driven changes in the Arctic Siberia mammoth population and the Late Pleistocene extinction problem. Quaternary Science Reviews, 2011, vol.30, pp. 2309-2328.

Nikolskiy P., Pitulko V.Evidence from the Yana Palaeolithic site, Arctic Siberia, yields clues to the riddle of mammoth hunting. Journal of Archaeological Science, 2013, vol. 40, pp. 4189-4197.

Otte M. The management of space during the Paleolithic. Quaternary International, 2012, vol. 247, pp. 212229.

Pavlov P.Y.The Paleolithic of northeastern Europe. Archaeology, Ethnology and Anthropology of Eurasia, 2008, no. 33, pp. 33-45.

Pitulko V.V.An Early Holocene Site in the Siberian High Arctic. Arctic Anthropology, 1993, vol. 30 (1), pp. 13-21.

Pitulko V. V. Chapter 16. Digging through permafrost in Siberia. Field Archaeology from Around the World. Ideas and Approaches. Heidelberg, New York, Dordrecht, London, Springer International Publishing Switzerland, 2015, pp. 111-113.

Pitulko V.V.Permafrost Digging. Encyclopedia of Global Archaeology. Cham, Springer, 2019. https://doi. org/10.1007/978-3-319-51726-1_1513-2

Pitulko V.V.The Berelekh Quest: A Review of Forty Years of Research in the Mammoth Graveyard in Northeast Siberia. Geoarchaeology, 2011, vol.26 (1), pp. 5-32.

Pitulko V.V.The Zhokhov Island Site and Ancient Habitation in the Arctic. Vancouver, Simon Frazer University, Archaeology Press, 2013, 202 p.

Pitulko V.V. Uchastok Iana B Ianskoi stoianki: nekotorye nabliudeniia, sdelannye v khode raskopok 20152018 godov. Pervobytnaia arkheologiia. Zhurnal mezhdistsiplinarnykh issledovanii, 2019, no. 1, pp. 6491. (In Russian)

Pitulko V.V., Basilyan A.E., Pavlova E. Y. Massovye skopleniia kostnykh ostatkov mamontov s priznakami deiatel'nosti drevnego cheloveka (r. Ilin-Syalakh, sever Iano-Indigirskoi nizmennosti). Zapiski IIMK RAN, 2013, no. 8, pp. 34-52. (In Russian)

Pitulko V.V., Basilyan A.E., Pavlova E. Y.The Berelekh Mammoth Graveyard: New Chronological and Stratigraphical Data from the 2009 field season. Geoarchaeology, 2014, vol. 29, pp. 277-299. 
Pitulko V. V., Ivanova V. V., Kasparov A. K., Pavlova E. Y. Reconstructing prey selection, hunting strategy and seasonality of the early Holocene frozen site in the Siberian high Arctic: A case study on the Zhokhov site faunal remains, De Long Islands. Environmental Archaeology, 2015, vol. 20, pp. 120-157.

Pitulko V. V., Pavlova E. Y. Geoarchaeology and Radiocarbon Chronology of Stone Age Northeast Asia. College Station, Texas A\&M University, 2016, 334 p.

Pitulko V.V., Pavlova E. Y. Kollektsii radiouglerodnykh datirovok, dlitel'nost' obitaniia liudei na stoiankakh kamennogo veka i khronometriia kul'turosoderzhashchikh otlozhenii Evraziia v kainozoe. Stratigrafiia, paleoekologiia, kul'tury, 2017, vol.6, pp. 136-143. (In Russian)

Pitulko V.V., Pavlova E.Y.Opyt radiouglerodnogo datirovaniia kul'turosoderzhashchikh otlozhenii Zhokhovskoi stoianki (Novosibirskie o-va, Sibirskaia Arktika). Zapiski IIMK RAN, 2015, no. 12, pp. 27-55. (In Russian)

Pitulko V.V., Pavlova E. Y.Permafrost as an Archaeological Environment. Geomorphic Processes and Geoarchaeology: from Landscape Archaeology to Archaeotourism. International conference held in Moscow-Smolensk, Russia, August 20-24, 2012. Extended abstracts. Moscow, Smolensk, Universum Publ., 2012, pp. 224-227.

Pitulko V.V., Pavlova E. Y., Basilyan A.E. Mass accumulations of mammoth (mammoth 'graveyards') with indications of past human activity in the northern Yana-Indighirka lowland, Arctic Siberia. Quaternary International, 2016, vol. 406, pp. 202-217.

Pitulko V. V., Pavlova E. Y., Basilyan A. E., Kritsuk S. G. Osobennosti vertikal'nogo raspredeleniia veshchestva v kraevykh oblastiakh merzlotnykh poligonov i ego znachenie dlia datirovaniia chetvertichnykh otlozhenii kriolitozony. Materialy VII-go Vserossiiskogo soveshchaniia po izucheniiu chetvertichnogo perioda: "Kvarter vo vsem ego mnogoobrazii. Fundamental'nye problemy, itogi izucheniia i osnovnye napravleniia dal'neishikh issledovanii", vol.2. Apatity, St. Petersburg, RAN Press, 2011, pp. 149-53. (In Russian)

Pitulko V.V., Pavlova E. Y., Nikolskiy P. A. Mammoth Ivory Technologies in the Upper Palaeolithic Arctic Siberia: a Case Study based on the materials from Yana RHS site. World Archaeology, 2015, vol. 47 (3), pp.333-389.

Pitulko V. V., Tikhonov A. N., Pavlova E. Y., Nikolskiy P. A., Kuper K. E., Polozov R. N. Early human presence in the Arctic: evidence from 45,000-year-old mammoth remains. Science, 2016, vol.351, pp. 260-263.

Pitulko V., Nikolskiy P., Basilyan A., Pavlova E. Chapter 2. Human habitation in the Arctic Western Beringia prior the LGM. Paleoamerican Odyssey. College Station, Texas A\&M University Press, 2013, pp. 13-44.

Pitulko V., Pavlova E., Nikolskiy P. Revising the archaeological record of the Upper Pleistocene Arctic Siberia: Human dispersal and adaptations in MIS 3 and 2. Quaternary Science Reviews, 2017, vol. 165, pp. 127-148.

Polyakov G. P., Shinakov E. A. Osnovy arkheologii. Bryansk, BGU Press, 2004, 138 p. (In Russian)

Popov V.V.Kosti mamonta v konstruktsii zhilishcha anosovsko-mezinskogo tipa na stoianke Kostenki 11 (Anosovka 2). Stratum plus, 2003-2004, no. 1, pp. 157-186. (In Russian)

Pryor A.J.E., Beresford-Jones D.G., Dudin A.E., Ikonnikova E.M., Hoffecker J.F., Gamble C.The chronology and function of a new circular mammoth-bone structure at Kostenki 11. Antiquity, 2020, vol. 94 (374), pp. 323-341.

Rapp G., Hill C. L. Geoarcheology. The Earth-Science Approach to Archaeological Interpretation. New Haven and London, Yale University Press, 1998, 274 p.

Razgildeeva I. I. Planigrafiia shestiochazhnogo kompleksa pozdnepaleoliticheskogo poseleniia Studenoe-2 v Zabaikal'e. Stratum plus, 2016, no. 1, pp. 243-263. (In Russian)

Rogachev A.N., Anikovich M.V.Pozdnii paleolit Russkoi ravniny i Kryma. Paleolit SSSR. Moscow, Nauka Publ., 1984, pp. 162-271. (In Russian)

Romanovskii N. N. Osnovy kriogeneza litosfery. Moscow, Moscow University Press, 1993, 336 p. (In Russian)

Rudenko S.I.Drevniaia kultura Beringova moria i eskimosskaia problema. Moscow, Leningrad, Glavsevmorput Publ., 1947, 135 p. (In Russian)

Sedov S. N., Aleksandrovskii A. L., Shishkov V.A., Benz M., Balabina V. I., Mishina T. N., Şahin F., Özkaya V. Anthropogenic Sediments and Soils of Tells of the Balkans and Anatolia: Composition, Genesis, and Relationships with the History of Landscape and Human Occupation. Eurasian Soil Science, 2017, vol. 50 (4), pp. 373-386. 
Slobodin S. B. Arkheologiia Kolymy i kontinental'nogo Priokhot'ia v pozdnem pleistotsene i rannem golotsene. Magadan, SVKNII DVO RAN Press, 1999, 246 p. (In Russian)

Smirnov V.N.Severo-Vostok Evrazii. Noveishaia tektonika, geodinamika i seismichnost' Severnoi Evrazii. Moscow, Probel Publ., 2000, pp. 120-133. (In Russian)

Sokoloff D.D., Sulerzhitskiy L.D., Tutubabin V.N. Vremia aktivnosti liudei na paleoliticheskikh pamiatnikakh po dannym radiouglerodnogo datirovaniia. Russian Archaeology, 2004, no. 3, pp.99-102. (In Russian)

Steele J. Radiocarbon dates as data: quantitative strategies for estimating colonization front speeds and event densities. Journal of Archaeological Science, 2010, vol.37, pp. 2017-2030.

Strakhov N. M. Tipy litogeneza i ikh evoliutsiia v istorii Zemli. Moscow, Gosgeoltekhizdat Publ., 1963, 534 p. (In Russian)

Sulerzhitskiy L.D. Vremia sushchestvovaniia nekotorykh pozdnepaleoliticheskikh poselenii po dannym radiouglerodnogo datirovaniia kostei megafauny. Russian Archaeology, 2004, no. 3, pp.103-112. (In Russian)

Sycheva S. A. Pochvenno-geomorfologicheskie aspekty formirovaniia kul'turnogo sloia drevnikh poselenii. Eurasian Soil Science, 1994, no. 3, pp. 28-33. (In Russian)

Todisco D., Bhiry N. Palaeoeskimo Site Burial by Solifluction: Periglacial Geoarchaeology of the Tayara Site (KbFk-7), Qikirtaq Island, Nunavik (Canada). Geoarchaeology, 2008, vol. 23, pp. 177-211.

Todisco D., Bhiry N., Desrosiers P. M. Paleoeskimo Site Taphonomy: An Assessment of the Integrity of the Tayara Site, Qikirtaq Island, Nunavik, Canada. Geoarchaeology, 2009, vol. 24, pp.743-791.

Vandenberghe J., French H. M., Gorbunov A., Marchenko S., Velichko A. A., Jin H., Cui Z., Zhang T., Wan X. The Last Permafrost Maximum (LPM) map of the Northern Hemisphere: permafrost extent and mean annual air temperatures, 25-17 ka BP. Boreas, 2014, vol. 43, pp. 652-666.

Velichko A. A. Paleoklimaty i paleolandshafty vnetropicheskogo prostranstva Severnogo polushariia. Pozdnii pleistotsen - golotsen. Moscow, GEOS Publ., 2009, 120 p. + 24 maps. (In Russian)

Velichko A.A., Grekhova L.V., Gribchenko Y.N., Kurenkova E.I.Pervobytnyi chelovek v ekstremal'nykh usloviiakh sredy. Stoianka Eliseevichi. Moscow, Nauka Publ., 1997, 192 p. (In Russian)

Velichko A.A., Grekhova L.V., Gubonina Z.P.Sreda obitaniia pervobytnogo cheloveka Timonovskikh stoianok. Moscow, Nauka Publ., 1977, 142 p. (In Russian)

Vereschagin N.K. Berelekhskoe "kladbishche" mamontov. Trudy Zoologicheskogo instituta, 1977, no.72, pp. 5-50. (In Russian)

Vereschagin N.K.O proiskhozhdenii mamontovykh kladbishch. Prirodnye obstanovki i fauny proshlogo, 1972, no. 6, pp. 131-148. (In Russian)

Waters M.R.Principals of Geoarchaeology: A North American Perspective. Tucson, University of Arizona Press, 1992, $401 \mathrm{p}$.

Wilczyński J., Wojtal P., Sobczyk K. Spatial organization of the Gravettian mammoth hunters site at Kraków Spadzista (southern Poland). Journal of Archaeological Science, 2012, vol. 39, pp.3627-3642.

Williams A.H.The use of summed radiocarbon probability distributions in archaeology: a review of methods. Journal of Archaeological Science, 2012, vol. 39, pp. 578-589.

Yanin V. L.Archaeologiia. Moscow, Moscow State University Press, 2006, 608 p. (In Russian)

Zaretskaya N.E., Gavrilov K.N., Panin A.V., Nechushkin R.I.Geokhronologicheskie dannye i arkheologicheskie predstavleniia o vremeni sushchestvovaniia opornykh pamiatnikov vostochnogo gravetta na Russkoi ravnine. Russian Archaeology, 2018, no. 1, pp.3-16. (In Russian)

Zolnikov I.D., Deev E.V., Slavinskiy V.S., Tsybankov A.A., Rybin E.P., Lysenko D. N., Stasyuk I.V. Geologicheskoe stroenie i postsedimentatsionnye deformatsii arkheologicheskogo pamiatnika Afontova gora-II (g. Krasnoiarsk, Sibir'). Russian Geology and Geophysics, 2017, vol. 58 (2), pp. 231242. (In Russian)

Статья поступила в редакцию 20 октября 2020 г. Рекомендована в печать 25 мая 2021 г. Received: October 20, 2020 Accepted: May 25, 2021 